\title{
Equality and Anti-Discrimination Legislation: An Uneasy Relationship
}

\author{
Margaret Thornton (D), Emerita Professor and Public Policy Fellow in the ANU College of Law
}

Australian National University, Canberra ACT, Australia

\section{ABSTRACT}

Despite the rhetoric of equality that infuses anti-discrimination legislation, a close analysis reveals that it is in-equality that is invariably privileged. With reference to the Australian example, this introductory article will show how the paradox is played out at multiple sites in terms of both form and substance, such as through the individualism and confidentiality of the complaint-based mechanism. A striking exclusion from the legislation is the attribute of class, the most significant manifestation of social inequality, which remains ineffable even when it significantly shapes other attributes. The prevailing political backdrop of neoliberalism plays a significant role in promoting inequality through competition policy and profit maximisation. Powerful corporations not only endeavour to resist transparency, but they also tend to oppose proactive measures in favour of substantive equality. The contradictions of anti-discrimination legislation thereby sustain in-equality while simultaneously espousing the rhetoric of equality.

Keywords - Equality, anti-discrimination legislation, neoliberalism, corporate power, positive action

Acknowledgements: Paper presented at 'Using Transparency to Achieve Equality', Academy of the Social Sciences in Australia Workshop (on-line), 30 November-1 December 2020. I thank the Academy for supporting the workshop and my co-organisers, Dominique Allen and Alysia Blackham, for their initiative and persistence in a difficult year.

Disclosure statement: No potential conflict of interest was reported by the author.

License: This work is under Attribution-NonCommercial-ShareAlike 4.0 International (CC BY-NC-SA 4.0)

https://creativecommons.org/licenses/by-nc-sa/4.0/

Suggested citation: Thornton, M. (2021). "Equality and Anti-discrimination Legislation: An Uneasy Relationship." Law in Context, 37 (2): 12-26, DOI: https://doi.org/10.26826/law-in-context.v37i2.149

\section{Summary}

1. Introduction

2. Endowing equality with a legal basis

3. Antidiscrimination legislation: The struggle to realise equality

4. The limitations of individualism

5. Towards substantive equality

5.1. Exceptions and exemptions

5.2. Proactive measures

6. Conclusion

7. References 


\section{INTRODUCTION}

The quest for equality is a powerful imperative of our times that has emerged in response to growing inequality. Equality is nevertheless an elusive and ambiguous concept with an ancient lineage and a substantial literature (e.g., Waldron 2008). For Aristotle, justice was "a kind of equality", but the conundrum he poses is "equality in respect of what?" (1959, §1282b). This question, which has preoccupied scholars for millennia, continues to be at the forefront. Its ambiguity is compounded by the fact that equality is a term of ordinary and practical use, and not a distinctively philosophical one (Wolgast 1980, p. 37). Many philosophical theories share the fundamental premise that "all humans are one another's equals", although the sense in which this is understood may differ. Nikolas Kirby (2015), for example, refers to these concepts as equal worth and equal authority. The first, equal worth, emanates from Judaeo-Christian theology, whereas "equal authority" is related to political thought that is grounded in differences arising from race, sex, class and education.

Equality in political thought derives from the democratic polity of classical Athens, where all citizens were deemed to be equal. While it was recognised that everyone was not created equal in terms of ability, equality was an attribute of the citizen's political or public life (Aristotle 1959, §1283a). However, as soon as we begin to interrogate the concept of citizenship, the inequality beneath the surface is exposed, for eligibility was restricted to a minority of the population, namely, free men, while women, slaves and metics (resident aliens) were excluded. Together with children, women and slaves were relegated to the private sphere, or household, where they were subject to a master. The homology between subordinated others and the private sphere has continued to mark it ever since as a realm of in-equality and un-freedom (Arendt 1958, pp. 28-37). Hence, it is apparent that the answer to Aristotle's question "equality in respect of what" will not be found in the private sphere qua home.

Today, we are compelled to put paid to any notion of a simple public/private dualism because the appellation "private" is also used to describe the myriad privately owned businesses that sustain the economy. To avoid confusion with the private sphere qua home, I refer to the private business sector as the 'market', which has grown phenomenally in recent years. It has not only colonised much of civil society and the domain of personal freedom, but it has also moved into the home with the aid of technology (Turkle 2011; Thornton 2016), a phenomenon that has been boosted by the injunction to work at home as a result of Covid-19 (Thornton 2021). The market also has public elements despite the favoured private nomenclature, for it is subject to regulation by the state. It nevertheless remains a sphere beset with ambiguity, as will be shown, as it is resistant to transparency as well as equality.

The importance of the market has expanded globally and locally, as a result of the neoliberal embrace, in which the state itself has been a key player (Peetz 2019, p. 3; Wacquant 2009, p. 306; Harvey 2005, p. 22). While the 'neo' in neoliberalism might suggest that laissezfaire has been revived and the market has grown of its own accord, this overlooks the critical role played by the state. Indeed, as Foucault (2008, p.1) recognises, "the art of government" under neoliberalism is imbricated with the market and profit maximisation. This can be seen with the privatisation of public goods, such as transport, utilities and education, as well as childcare, aged care, and welfare services. Instead of being supported by the public purse, these entities are now not only expected to be self-supporting but to be generators of profit.

Under social liberalism, the state attempted to effect a modicum of distributive justice through a robust social welfare system and progressive taxation. Unsurprisingly, AD (anti-discrimination) legislation has its genesis within social liberalism. While committed to the free market, the excesses of profit maximisation were restrained by a commitment to a philosophy of egalitarianism and collective good. In contrast, neoliberalism emphasises individualism, capital accumulation and the "good of the economy" (Purcell 2008, p. 2), but this does 
not bode well for a more equal society, particularly as it expressly champions freedom over equality. Freedom and equality are the twin variables of classic liberalism, although they do not sit easily together. As Wendy Brown (1995, p. 67) argues, when social liberalism with its commitment to distributive justice is in the ascendancy, it engenders resentment on the part of the rich and powerful who agitate against measures designed to effect equality in favour of untrammelled freedom.

The neoliberal turn has significant ramifications for workers' rights, which have been eroded, particularly in terms of the casualisation and intensification of work (Peetz 2019, pp. 10-12). Indeed, neoliberalism often involves replacing state regulation with markets (Peetz 2019 , p. 41), which involves a shift from the best interests of workers to the maximisation of wealth in the interest of corporate elites (Glasbeek 2017, p. 229). The net effect is that the state, hand- in-glove with the market and competition policy, is directly or indirectly engaged in the promotion of in-equality while continuing to espouse a commitment to equality, an observation that has also been made in respect of the mixed human rights record of recent years (e.g., MacNaughton 2018; Moyn 2014, p. 149).

Neoliberalism has brought about a significant change in the character of the market itself. While it continues to include multiple small businesses, globalisation has given rise to a proliferation of powerful multinational corporations to which the state increasingly defers (Crouch 2014, p. 115). The operating budgets of some multinationals may exceed the gross national product of nation states, and their Chief Executive Officers (CEOs) have the power to secure direct access to prime ministers and presidents. They may also seek to be registered offshore, such as in the Cayman Islands, to evade regulation and avoid paying taxation (Glasbeek 2017, pp. 17-19). The pronounced move in favour of corporatisation also points to the decoupling of profits and productivity from wages that is a distinctive feature of neoliberalism (Peetz 2019, p. 108). The curious legal constitution of corporations, wittily referred to by Glasbeek (2017, p. 9) as "law's gift to capitalists", enables them to resist attempts at transparency by individuals alleging discrimination. A corporation may assiduously resist a complaint of discrimination through appellate courts where its power and wealth enable it to write the jurisprudence in its own interests, just as the victors of war write the authoritative histories.

The rhetoric in favour of social and political equality has been thwarted by a sharp rise in economic inequality all over the world, as demonstrated by compelling recent studies, such as those of Walter Scheidel (2017) and Thomas Piketty $(2014,2020)$. In his study of the history of inequality since the Stone Age, Scheidel (2017, p. 421), for example, points out that the richest one per cent of households has risen sharply since the 1970s and 1980s, most notably in Australia and the United States. This one per cent holds more than half of all global private net wealth. As Rousseau (1966) recognised two centuries ago, social and political equality is contingent on economic equality, an observation that poses a major conundrum for AD legislation.

In this article, paying particular attention to the Australian example, I overview the uneasy relationship between equality and AD legislation in light of the neoliberal turn that has engendered such ambivalence about equality. I critically analyse the constitutive elements of the substance and procedure of the legislation to show how it insidiously undermines the idea of equality, despite the rhetoric. The neoliberal focus on profit maximisation has boosted the resistance to discrimination complaints (cf. Dinner 2017). Indeed, Tristan Green (2017), in her analysis of the growth of corporate power in the United States, invokes the metaphor of "discrimination laundering" to encapsulate the way this has raised the probative bar for complainants, causing racism and sexism to disappear. She argues that organisations are increasingly found to be 'innocent' when rogue employees have been found to act on socially constructed biases against the organisation's interests (Green 2017, p. 1). In ways such as this, corporations use their power and superior resources effectively to neutralise a complaint of unlawful discrimination. As the neoliberal state actively promotes profit maximisation while paying lip service to equality through $\mathrm{AD}$ 
legislation, the contradictions suggest that the hope for greater transparency may prove to be unduly optimistic.

\section{ENDOWING EQUALITY WITH A LEGAL BASIS}

The classical liberal understanding of equality is largely restricted to formal equality or equality before the law, a conceptualisation that underpins the Anglo-Australian legal system. Formal equality accepts the basic Aristotelian principle that like cases should be treated alike. However, as Bailey (2009, p. 400 ff.) points out, a subjective choice involving values must be made in determining equivalence. A formalistic understanding pays scant attention to the Rawlsian concept of justice that inequalities of wealth and authority are just only if they result in compensating benefits for everyone, particularly for the least advantaged members of society (Rawls 1972, pp. 14-15). When strictly applied, formal equality disregards the disproportionate impact it may have on those who are differently situated. Anatole France's well-known aphorism that the rich as well as the poor are prohibited from sleeping under the bridges of Paris illustrates the point (France 1898, p. 117). In certain circumstances, Australian courts have acknowledged that justice may demand a liberal interpretation, ${ }^{1}$ but for the most part, they have preferred to construe equality in narrow formalistic terms and slough off the subjectivity of an individual's circumstances. ${ }^{2}$ The adjudicative principle of "strict and complete legalism", associated with noted Australian High Court judge, Owen Dixon (Gava 2010), might have something to do with the resilience of legal formalism.

The absence in the Australian Constitution of an express guarantee of equality comparable to that of the US Constitution has meant that the concept of equality has rarely been imagined by the High Court as the prerogative of citizens. An exception was Leeth $v$ Commonwealth, ${ }^{3}$ in which Deane and Toohey JJ, together with
Gaudron J, sought to read an implied guarantee of equality into the Australian Constitution. ${ }^{4}$ Although the tenor of the judges' observations is directed to the relatively narrow interpretation of equality before the law, the express reference in both judgments to 'equal justice' ${ }^{6}$ suggests that they envisaged something more than same treatment, perhaps along the lines articulated by Rawls (1972). Deane, Toohey and Gaudron JJ nevertheless comprised the minority in Leeth and their views have not found favour with subsequent members of the Court in the decades since Leeth was decided.

In view of the absence of a constitutional guarantee of equality, there have been various attempts to enact a statutory bill of rights at the federal level, all of which have failed (e.g., Williams 1999, p. 250 ff.). The Australian Capital Territory (2004), Victoria (2006) and Queensland (2019) have enacted legislation along the somewhat limited dialogic model, which entails a dialogue between the executive, the parliament and the judiciary (e.g., Commonwealth of Australia 2009), but it is one that falls short of the conferral of substantive rights.

$\mathrm{AD}$ legislation is the closest we have to a legislative instrument enjoining equality, although it is far from a guarantee. A person aggrieved merely has a right to lodge a complaint with an agency, which is responsible for attempting to conciliate it in the first instance. I would therefore take issue with Taylor, who asserts that the legislation protects individuals from discriminatory treatment (2019, p. 202). While the hope might be that a proven instance of discrimination may foreclose similar instances in the future, the individualised focus in which each complaint of discrimination is treated as discrete means that this cannot be relied upon. Equal opportunity - or equal employment opportunity (EEO) means merely that an applicant for a job can expect to be considered on their merits without regard to any of the proscribed characteristics, a requirement that falls

\footnotetext{
${ }^{1}$ Eg, Maloney v The Queen (2013) 252 CLR 168.

2 Eg Sahak v Minister for Immigration and Multicultural Affairs (2002) 123 FCR 541; Munkara v Bencsevich \& Ors. [2018] NTCA 4.

3 (1992) 174 CLR 455.

${ }^{4}$ Leeth $v$ Commonwealth 483, 485, 489, 491 (Deane and Toohey JJ); 502 (Gaudron J).

${ }^{6}$ Leeth $v$ Commonwealth 487 (Deane and Toohey JJ); 502 (Gaudron J).
} 
far short of a guarantee of equality.

I suggest that the unwillingness to move beyond a formalistic interpretation of equality has been Influenced by its long history within liberal legalism, most recently by Owen Dixon and the jurisprudence of the High Court.

\section{THE NON-DISCRIMINATION PRINCIPLE AND THE STRUGGLE TO REALISE EQUALITY}

AD legislation proscribes discrimination in public life, broadly construed to include civil society and the market. Employment, education, accommodation and the provision of goods and services are the primary areas where discrimination is proscribed. I reiterate that the legislation leaves untouched the private sphere qua home, just as in the classical model of liberal legalism, where women continue to be overwhelmingly responsible for the preponderance of (unpaid) housework and caring (e.g., Diversity Council Australia 2019), whether engaged in paid work or not, an inequity that is immunised against challenge.

$\mathrm{AD}$ legislation is a social liberal initiative that was introduced to assist women and subordinated others in the struggle to be admitted to public life as the equals of Benchmark Men (i.e., those who are Anglo-Celtic, heterosexual, able-bodied, middle class, who are neither too young or too old, and who favour a nominal Christian religion (if any) and a slightly right-of-centre politics). The raison d'être of the non-discrimination principle is that rewards are distributed according to talents but, as Rawls points out, the distribution of natural talents is arbitrary (1972, pp. 311-12). Hence, the focus of Equal Opportunity (EO) is directed to the starting points, after which inequalities between candidates may emerge, depending on ability and personal effort (e.g., O'Donovan and Szyszczak 1988, p. 4).

The characteristics in respect of which discrimination is proscribed vary between each of Australia's nine jurisdictions; the Equal Opportunity Act 2010 (Vic) s. 6, for example, lists 18 discrete attributes. Race and sex/gender are the paradigmatic attributes, although several attributes believed to be ancillary to sex have been added, beginning with marital status, followed by pregnancy or potential pregnancy, breastfeeding, family responsibilities, sexual orientation, gender identity and intersex status. Disability and age were also added as discrete grounds at the federal level, and a range of other attributes, such as religion, have been included within most State and territory jurisdictions. AD law prefers to focus on a single characteristic, although commentators have long argued in favour of the intersection of two or more grounds in cases when they cannot be easily separated (e.g., Afrey 2019; O'Connell 2019; Crenshaw 1989). It seems that this intersectionality theory has made more progress at the international level than the municipal level (e.g., Goldblatt 2015).

It is nevertheless notable that $\mathrm{AD}$ legislation omits what is probably the most significant indicium of inequality, that is, class, or social status, which is starkly revealed by the strong redistribution of wealth upwards towards the wealthy elite (Piketty 2020, p. 3 et seq.; Peetz 2019, p. 39; Scheidel 2017). 'Social origin' is included in ILO 111 (Convention concerning Discrimination in respect of Employment and Occupation), but this characteristic or a cognate characteristic has been largely resisted by most Western liberal democratic capitalist jurisdictions (Thornton 2018). Although national and multinational corporations are the primary wealth creators of the neoliberal state, they contribute significantly to social inequality, as suggested, but are largely protected from scrutiny, as any serious attempt to achieve equality could disrupt the functioning of capitalism as an economic system (Freeman 1982, p. 10). Economic inequality may nevertheless intersect with attributes such as race, sex, disability and/or age. While individual shareholders benefit from the distribution of profits, the corporate veil facilitates a lack of transparency regarding a corporation's operations and underscores the inherent conflict between capitalism and equality (Callinicos 2000, p. 132).

Philip Green observed 40 years ago that the advances of capitalism have "everywhere deepened the social division of labour and inequality on the one hand, while inspiring and broadening the search for more equality on the other" (Green 1980, p. 1). The flowering of neoliberalism, with its emphasis on profit maximi- 
sation, has accentuated the extent of inequality in contemporary society and is supported by data attesting to the rise in inequality since the 1980s (Scheidel 2017, pp. 405-406). Ironically, this was around the time that AD legislation began to be enacted in Australia, which underscores the contradictory nature of social change: that is, as inequality increases, it engenders agitation for equality. Perhaps influenced by the ineffability of class within $\mathrm{AD}$ legislation and liberal legalism more generally, discrimination scholars have tended to shy away from issues of class and the growing economic inequality. It may be that a focus on economic rights within an international human rights context is regarded as more productive (e.g., Goldblatt 2017).

Class inequality is understood by Marx (1938, pp. 10-11) to be the basis of social inequality, which is measured by one's relationship to the ownership of the means of production. Marx believed that class struggle arose because capitalists (non-workers) expropriated the means of production from workers. Social liberalism of the $20^{\text {th }}$ century sought to address the inequity at the margins through redistributive policies but, recently, the more pronounced focus on productivity, performativity and profits has derailed the search for equality, other than in a formalistic sense. Even though equality is described as the fundamental value underpinning antidiscrimination legislation (Gaze and Smith 2016, pp. 10 et seq.), worker security has become more parlous under neoliberalism. Employment is conventionally the source of the majority of AD complaints (Australian Human Rights Commission 2019, p. 2), and Harvey describes the "disposable worker" as prototypical under neoliberalism $(2005$, p. 169$)$. If it is not profitable to retain workers, a corporation may shed them within the rubric of 'workplace restructuring', which is regarded as a legitimate defence to a complaint of discrimination (Thornton 2008). ${ }^{5}$ It is also notable that governments themselves feature as parties in discrimination litigation and are prepared to expend public resources on appeals in an endeavour to maintain the status quo. ${ }^{6}$ This underscores not only the ambivalence of the neoliberal state towards the equality prescript contained in its own legislation, but also the way the intersection between neoliberalism and AD law has created blind spots in contemporary understandings of equality (Dinner 2017, p. 1113). Neoliberalism thereby fosters inequality through corporate power, capital accumulation and competition policy, while simultaneously blurring the line between management, bullying and harassment.7

\section{THE LIMITATIONS OF INDIVIDUALISM}

Given liberal legalism's favouring of formalism, the individual complaint-based model, or what Freeman (1982) calls the "perpetrator perspective", is typical of AD legislation. The initial tranche of complaints tended to focus on instances of direct discrimination that were overt, such as denying a woman a job because of her sex, regardless of merit. ${ }^{8}$ Second generation complaints often involved instances of indirect discrimination buried deep within the social psyche, which tend to be less tractable to remediation. ${ }^{9}$ Subconscious bias, for example, may manifest itself as favouritism for a member of the dominant group by the over-attribution of positive behaviour, which is a familiar scenario displayed in the preference for Benchmark Men in positions of authority. The problem leads to a fundamental attribution error in which the discrimination is attributed to an individual discriminator rather than the environment. As Krieger points out, people then have a hard time recognising discrimination on a case-by-case basis (1999, p. 1309), despite the denial of opportunity to the individual. To be effective, protection from discrimination needs to cut deep into "organizational structures and institutionalized practices of employment" (Somek 2011, p. 168). Only then can the individual case be seen to be part of a

\footnotetext{
${ }^{5}$ E.g., Commonwealth Bank of Australia v Human Rights and Equal Opportunity Commission (1997) 80 FCR 78.

6 E.g., State of Victoria v Schou (No 2) 2004) 8 VR 120; New South Wales v Amery (2006) 226 ALR 196.

7 The very high rate of sexual harassment in the workplace is revealed by recent Australian and international studies (e.g., Australian Rights Commission 2020; Pender 2019).

8 E.g., denial of opportunity to train as an airline pilot; see Ansett Transport Industries (Operations) Pty Ltd v Wardley (1980) 142 CLR 237.

${ }^{9}$ E.g., New South Wales v Amery (2006) 226 ALR 196.
} 
systemic pattern. The failure to recognise cognitive bias gives rise to the "organizational innocence" through discrimination laundering referred to by Green (2017, p. 33). As indirect discrimination is legally complex and poorly understood, there has been a preference for the more straightforward individualised instances of direct discrimination. The legislation may be able to capture the materiality of discrimination close to the surface, but it is unable to grapple with systemic bias buried deep within the social psyche (Thornton 2015, pp. 321-325).

Can Big Data aid transparency in the case of corporate respondents? Although it does not constitute proof of discrimination, Big Data may raise a presumption of discrimination. Statistical data has been used in the US in conjunction with other social science evidence to show the extent of discriminatory practices within an organisation in what is known as "systemic disparate treatment theory" (Green 2017, pp. 67 ff.). Statistical evidence was first used in International Brotherhood of Teamsters v United States (431 US 324) [1977] when it was alleged that a trucking company had failed to place Black and Latino truck drivers into the more lucrative long-haul positions. The statistical data revealed a stark disparity between the percentage of Black and Latino drivers and the population surrounding the company's terminals. Such evidence can transcend the individual instance by supporting an inference of discrimination.

Accordingly, the use of Big Data could make a difference in the occasional representative case or class action, where there is a large employee or customer base, the members of which are similarly situated. However, the data is always subject to the propensity to being 'laundered' by corporate respondents because of their power. O'Neil also cautions against the use of large-scale mathematical models because they are optimised for efficiency and profitability rather than for justice (2016, pp. 129-30). She argues that because the algorithms are poor, they over-simplify complex problems and contribute to inequality (O'Neil 2016, pp. 150, 199). Of particular significance for AD scholarship is O'Neil's observation that the models used can encode human prejudice and bias into software systems (O'Neil 2016, p. 3).

While complainants may lodge a complaint in the hope of making transparent an individual instance of discrimination, they rarely succeed in achieving this aim. Indeed, a lack of transparency is central to the favoured model of dispute resolution. The initial process of conciliation, which occurs behind closed doors, is entirely confidential (Allen and Blackham 2019; Thornton 1990, pp. 143-170) and, even if settled, the terms are likely to be the subject of a non-disclosure agreement. A minuscule percentage of complaints - barely two per cent - proceed to a formal hearing in open court, where justice ostensibly "needs to be seen to be done" (Allen \& Blackham 2019, pp. 414-417). However, a corporate respondent is not only likely to have a monopoly over the evidence but also the means to fund the crafting of a sophisticated defence by engaging prestigious counsel, which is beyond the means of most complainants. Indeed, many complainants cannot afford representation at all and the evidence shows that unrepresented individuals do not fare at all well against corporate respondents, however worthy their claims. ${ }^{10}$

Thus, while AD legislation might appear to be a form of social legislation that is distributive in orientation, it does not recognise a distributive pattern (Somek 2011, p. 17). The legislation purports to exhibit a special moral concern for the victims of discrimination and stereotyping, but the market context all too often skews the outcome against them. As a result, corporate wealth invariably causes AD law to fall short of realising its modest aim, leading Somek to describe the resulting social policy as a state of "disempowerment by competitiveness" (2011, p. 178).

\footnotetext{
10 There are dozens of reported cases supporting this proposition, although one can only surmise that complainants might have fared better had they been represented. See, e.g., Frost v TAFE NSW [2020] NSWCATAD 219 (disability); DLH v Nationwide News Pty. Ltd. (No. 2) [2018] NSWCATAD 217 (transgender); Findley v MSS Security Pty. Ltd. [2017] FCCA 2898 (disability); Duncan v Chief Exec., Office of Environment and Heritage No. 2 (2013) NSWADT 78 (race); Liria v Papuan Oil Search Ltd. [2012] NSWADT 73 (race).
} 


\section{TOWARDS SUBSTANTIVE EQUALITY}

Despite its limitations, AD legislation is ostensibly 'radical' in extending the right to complain about unequal treatment to women, Indigenous people, LGBTIQ people, people with a disability, and disfavoured others. As they were historically excluded from the community of equals, these people generally had no right to complain at common law. Nevertheless, the individualised complaint-based mechanism treats each alleged act of discrimination as the aberrant or "rogue" act of an individual perpetrator (Green 2017, p. 59), and effectively deflects attention away from the systemic nature of inequality. Residual resistance and ambivalence persist in the form of exceptions, qualifications and uncertainties, particularly regarding sex and sexuality (Thornton 2015, p. 318). Not only does the individual complainant have a low chance of success, but individualisation is also a limited avenue for effective substantive change (Green, 2017, p. 52).

Substantive equality is not explicable in terms of a single principle. Sandra Fredman (2011, p. 25) argues for four overlapping aims in a multidimensional strategy: first, it is necessary to break the cycle of disadvantage associated with status or out-groups, thereby reflecting the redistributive dimension of equality. Secondly, it is necessary to promote the dignity and worth of an identity group to reduce stigma and reflect the recognition of the worth of members. Thirdly, it is necessary to accommodate difference and aim for structural change in order to capture the transformative dimension, and fourthly, it is necessary to aim for full participation of women and members of a group in society. Equality also requires that attention be paid to associational and interdependent relations, which is where the capabilities perspective of Amartya Sen (2009) makes most sense. For Sen, individualisation has a particular meaning, for he argues that it is essential that we should all live as we would like and to promote the ends we want (2009, p. 228). However, this would necessitate an understanding of equality that went far beyond the for- malistic rhetoric of same treatment to address the material reality of inequality, understood in terms of subjective needs and desires. The possibility of realising such an ambitious aim within existing AD framework, to which I turn, is unlikely, particularly in view of the way neoliberalism privileges dominant interests (cf. Dinner 2017).

\subsection{EXCEPTIONS AND EXEMPTIONS}

Given the preference for formalism and same treatment within the Anglo-Australian legal culture, courts have generally required express legislative exceptions in $\mathrm{AD}$ legislation, such as special measures, to give effect to even a modest understanding of substantive equality. The phrase "special measures" is deployed in the text of the United Nations (UN) Conventions and replicated in Australian legislation. However, its meaning is poorly understood and the language confusing, as Rees, Rice and Allen (2018, p. 185) point out with reference to the ambiguous phrase "positive discrimination" used in the Age Discrimination Act 2004 (Cth) s. 33. The jurisprudence on special measures has been similarly unhelpful. The Australian High Court was first confronted with special measures in Gerhardy v Brown, ${ }^{11}$ in which the central question was whether exclusive access to lands by Indigenous people under the Pitjantjatjara Land Rights Act 1981 (SA) constituted a special measure under the Racial Discrimination Act 1975 (Cth), s. 10. Although the Court was unanimous in upholding the validity of the State Act, the judges offered scant justification as to why it qualified as a special measure, thereby providing little assistance to subsequent litigants wrestling with the ambit of the term (Sadurski 1986). ${ }^{12}$

Exemptions from AD legislation, which give permission for certain activity to take place that would otherwise be discriminatory, may be sought by organisations on a case-by-case basis. For example, in order to obtain access to US aerospace technology, a number of powerful defence-contracting companies, such as Boeing,

\footnotetext{
11 Gerhardy v Brown (1985) 159 CLR 70.

12 See also, e.g., Maloney v The Queen (2013) 252 CLR 168, and the casenote by Rice (2013)
} 
applied for and successfully obtained exemptions from the proscription of race discrimination in all States and territories except Tasmania (Thornton and Luker 2010). These exemptions have been periodically renewed. ${ }^{13}$ They clearly illustrate the deference to corporate power and the appeal of the profit motive, particularly when substantial interests of a political nature are involved. Morris J, in upholding the exemption in Victoria, likened the US to the elephant in the room: "Like it or not, the United States is the world power and controls key aerospace technology".14 In deferring to the power of the US, we see the legitimisation of discriminatory conduct, an example of rational discrimination, which Goldberg (2002, p. 228) identifies as the "handmaiden of racelessness".

\subsection{PROACTIVE MEASURES}

Affirmative action (AA) entails the crafting of proactive mechanisms by institutions and it would appear to be the most effective means of realising substantive equality. It recognises that discrimination is invariably systemic and that organisations, particularly employers, have an obligation to foreclose the possibility of complaints. The Australian experience of AA was nevertheless relatively short-lived because of resistance on the part of employer groups and corporate interests. While AA was used in official discourse for a time, it fell from favour with the neoliberal turn barely a decade later and was replaced with the somewhat weaker 'positive duties'. I outline the American experience of AA, which is a clear illustration of how proactive measures are intended to work, as well as underscoring the antipathy on the part of powerful interests. Indeed, the fallout from the leading American Supreme Court case contributed to the resistance towards AA in Australia just when the first legislative initiatives were being contemplated.

In Bakke, ${ }^{15}$ the University of California at Davis set aside 16 places out of 100 for minority students in its medical school. Bakke, a white male, was denied entry but argued that but for his race he would have been admitted as he had a higher test score. By a narrow margin, the set-aside was struck down by the Supreme Court as contravening the Equality Clause of the Fourteenth Amendment of the Constitution. An acrimonious debate ensued concerning the validity of quotas as a mechanism for achieving racial equality (e.g., Clayton and Crosby 1992, p. 104). In accordance with the ressentiment of the right thesis, victim-blaming and backlash became the order of the day (e.g., Lawrence and Matsuda 1996, p. 47; Bergmann 1996). Preferential hiring was also criticised for benefiting individuals rather than the group as a whole (Jarvis Thomson 1977). These issues came to be imbricated with the question of whether AA programmes are compensatory and designed to remedy past injustices or whether they should focus on ensuring equal opportunity for women and minorities in the present day (Goldman 1979, p. 200).

Detractors argued that AA constituted "reverse discrimination" or "preferential treatment" because it ran counter to "hiring by competence" (Goldman 1979, p. 14) and thereby constituted a threat to meritocracy (Lawton 2000, p. 598). Other critics argued that the principle of merit is neither neutral nor objective (Krieger 1999, pp. 1293ff.), as it consistently gives way to privilege and wealth (Lawrence and Matsuda 1997, pp. $96 \mathrm{ff}$.). Not only does merit carry with it the myth of objectivity, it also carries the belief that discrimination on the basis of sex or race is a thing of the past (Lawton 2000 , p. 594). Some women and minorities also claimed that they felt demeaned by AA as they believed it reinforced negative stereotypes (Krieger 1999, p. 1263). Many of these criticisms were subsequently echoed in Australia (e.g., Moens 1985).

Minimalist AA legislation was enacted in Australia in 1986 after the AA provisions in Senator Susan Ryan's draft Sex Discrimination Bill of 1983 were removed (Thornton and Luker 2010). The Affirmative Action (Equal Opportunity for Women) Act 1986 (Cth) (AA Act), placed an obligation on employers with more than 100 employees to prepare a plan designed to improve the

13 Defence Export Controls | Business \& Industry | Exports | Department of Defence Accessed 12/12/2020.

14 Boeing Australia Holdings Pty. Ltd. [2007] VCAT 532 at [42].

15 Regents of University of California v Bakke 438 US 165 (1978). 
position of women in their workplaces and to lodge an annual report. Unlike complaint-based AD legislation, the AA Act lacked any enforcement mechanism; its only sanction was to name a transgressor in Parliament for failure to lodge a plan, about which employers were dismissive (Strachan and Burgess 2000). Contract compliance was also introduced for government contractors but there is no evidence that it was ever used.

The myth that AA mandated quotas entailing the appointment of unqualified women nevertheless haunted the life of the AA Act until it was repealed. It was then replaced with the Equal Opportunity for Women Act 1999 (Cth), which removed all references to AA as well as to 'objectives' and 'forward estimates' lest they be construed to mean quotas. However, this iteration was also short-lived because of attacks by the business community and it was replaced with the present legislation, the Workplace Gender Equality Act 2012 (Cth), which further rationalised reporting requirements.

The neoliberal turn led not only to the evisceration of AA, but the word 'equality' itself became suspect and began to disappear from the public policy agenda (Thornton 2015, pp. 325-328; cf. Shulman 2018, p. 11). For example, in 2008, the phrase 'equal opportunity' was removed from the title of the 'Human Rights and Equal Opportunity Commission' to become the 'Australian Human Rights Commission'. In addition, 'managing diversity', an anodyne concept that had emerged in the US in the 1980s, replaced equal opportunity as the favoured official phrase (Bacchi 2000). 'Managing diversity' did not carry with it the discomfiting antinomy of inequality. Somek suggests that the second generation of anti-discrimination scholarship in Europe similarly shifted from a focus on state legislation to managerial strategies that included diversity training for employees (2011, p. 175). He argues that such a strategy enabled the "purity of the market economy" to remain unchallenged (2011, p. 175).

While there are some recent instances of proactive legislation in the more progressive Australian States, such as the Equal Opportunity Act 2010 (Vic.) ss. 15-16, the extent of the positive duty is not clearly delineated. Furthermore, the Gender Equality Act 2020 (Vic) mandates 'positive duties' in the public sector only and does not create legal rights. While the language of AA has become passé, the new initiatives echo the public sector initiatives of the 1970s and 1980s (e.g., Radford 1985; Wilenski 1977) when social liberalism was in the ascendancy. While positive duties are ostensibly designed to overcome the reactive and negative approach underpinning the individual complaint-based mechanism, it is doubtful, as Rice argues (2010, p. 228), whether legislation mandating substantive equality measures is likely to emerge in Australia in the foreseeable future. Indeed, it is notable that no legislative proposal designed to effect substantive equality has ever been taken seriously, which includes the Australian Law Reform Commission's draft Equality Act of 1994 (Graycar and Morgan 2010). The "hyper-inegalitarian narrative" that has taken hold of our society (Piketty 2020 , p. 3) is intent on capital maximisation, which precludes the realisation of a substantive understanding of equality.

\section{CONCLUSION}

$\mathrm{AD}$ legislation is restricted to specified attributes in strictly delineated areas of public life, while inequities in private life are immunised from scrutiny. Even then, some attributes may be subject to exceptions if their inclusion continues to be contentious, as is the case with sex and sexuality. Furthermore, social status, the key indicium of inequality in our society, is not proscribed. More insidiously, a commitment to formalism, with its myth of equality of bargaining power, occludes the way that corporate respondents can use their power and resources in such a way as to 'launder' complaints of discrimination (Green 2017). All these factors constitute powerful impediments to developing greater procedural transparency in the interests of equality.

While substantive initiatives are the only effective way to address systemic discrimination, a brief overview of the underwhelming attempts to develop proactive strategies reveals the resistance on the part of powerful entities towards even a modest suggestion of equality for women and others. The neoliberal turn, with its adulation of the market, has accentuated 
inequality through competition policy and profit maximisation, as the market metanarrative is consistently privileged over the realisation of individual capabilities (Sen 2009; Nussbaum 2011). Big Data may well assist in providing a modicum of transparency by identifying structural inequality, but its effectiveness must be closely monitored in light of O'Neil's critique (O'Neil 2016). Overall, AD legislation is a very blunt tool for achieving equality in a neoliberal climate (cf. Somek 2011, p. 158).

According to Scheidel's analysis (2017), only war, revolution, state collapse and pandemics - what he terms "the Four Horsemen of the Apocalypse" - have been capable of effecting a modicum of equality throughout human history. His thesis is bleak, however, because the Four Horsemen, in their endeavour to contain inequality, bring catastrophic loss of life, destruction and misery with them. In each case, inequality was capable of being mitigated only because massive labour shortages resulting from the calamity heightened demand and led to a transfer of wealth from the rich to the poor. Comparable labour shortages today are unlikely because the death rate from the contemporary pandemic, COVID-19, has been contained due to mandatory lockdowns, social distancing and improved health care, including effective vaccines. Indeed, the fact that multiple workers are either unemployed or their jobs are in jeopardy because of the pandemic points to an oversupply of labour (Hayne 2020), which puts paid to the applicability of Scheidel's thesis today.

Piketty (2014) proposes a less Draconian solution to overcoming the problem of inequality than one that is predicated on a massive loss of life. He advocates the regulation of capital to strengthen the welfare state, including a return to progressive taxation so that the rich pay more, and measures are taken to prevent individuals and corporations from engaging in tax avoidance. We know that these measures work as the history of social liberalism in the $20^{\text {th }}$ century reveals. COVID-19 could theoretically act as a catalyst for reform as governments around the globe inject billions of dollars into initiatives designed to effect recovery of their economies. But will such initiatives succeed in bringing us closer to the ideal end state of equality? Only if the stranglehold of neoliberalism with its commitment to competition policy and profit maximisation loosens its hold and a substantial taxation impost is levied on wealthy individuals and corporations. As it is unlikely that will occur any time soon, we are compelled to rely on the prevailing model of $\mathrm{AD}$ legislation with its emphasis on the rhetoric rather than the reality of equality.

\section{REFERENCES}

1. Afrey, S. 2019. Intersectional Discrimination. Oxford, UK: Oxford University Press.

2. Allen, D. and Blackham, A. 2019. "Under Wraps: Secrecy, Confidentiality and the Enforcement of Equality Law in Australia and the United Kingdom". Melbourne University Law Review, 43 (2): 384-422.

3. Arendt, H. 1958. The Human Condition. Chicago, USA: University of Chicago Press.

4. Aristotle. 1959. Politics. Ed. and trans. John Warrington. London: Everyman's Library, Dent.

5. Australian Human Rights Commission. 2020. Respect@Work: National Inquiry into Sexual Harassment in Australian Workplaces. https://humanrights.gov.au/our-work/sex-discrimination/publications/respectwork-sexual-harassment-national-inquiry-report-2020 Accessed 12/12/2020

6. Australian Human Rights Commission. 2019. 2018-19 Complaint Statistics. https://humanrights.gov.au/sites/default/files/2020-10/AHRC AR 2019-20 Complaint Stats FINAL.pdf

7. Bacchi, C. 2000. "The Seesaw Effect: Down goes Affirmative Action, up comes Workplace Diversity". Journal of Interdisciplinary Gender Studies, 5 (2): 64-83.

8. Bailey, P. 2009. The Human Rights Enterprise in Australia and Internationally. Chatswood, N.S.W. Australia: LexisNexis Butterworths.

9. Bergmann, B. R. 1996. In Defense of Affirmative Action. New York, USA: Basic Books.

10. Brown, W. 1995. States of Injury: Power and Freedom in Late Modernity. Princeton, NJ, USA: Princeton University Press, 1995. 
11. Callinicos, A. 2000. Equality. Cambridge, UK: Polity.

12. Clayton, S. D. and Crosby, F. J. 1992. Justice, Gender, and Affirmative Action. Ann Arbor, USA: University of Michigan Press.

13. Commonwealth of Australia. 2009. National Human Rights Consultation Report (Brennan Report). Canberra: Attorney-General's Department.

14. Crenshaw, K. 1989. "Demarginalizing the Intersection of Race and Sex: A Black Feminist Critique of Antidiscrimination Doctrine, Feminist Theory and Antiracist Politics." University of Chicago Legal Forum, 1/8: 139-167.

15. Crouch, C. 2014. "Putting Neoliberalism in its Place.” The Political Quarterly, 85 (2): 114-121.

16. Dinner, D. 2017. “Beyond 'Best Practices': Employment Discrimination Law in the Neoliberal Era." Indiana Law Journal, 92 (3): 1059-1118.

17. Diversity Council Australia. 2019. Let's Share the Care at Home and Work: A Call to Action to Reduce the Gender Pay Gap. Sydney: Diversity Council Australia Ltd.

https://www.dca.org.au/sites/default/ files/share the care accessible.pdf

Accessed 12/12/2020.

18. Foucault, M. 2008. The Birth of Biopolitics: Lectures at the Collège de France, 1978-1979. Ed M Senellart, Trans. G Burchell. New York, USA: Palgrave Macmillan.

19. France, A. 1898. The Red Lily (Le Lys Rouge). New York, USA: Brentanos.

20. Fredman, S. 2011. Discrimination Law. Oxford, UK: Oxford University Press, 2nd edn.

21. Freeman, A. D. 1982. "Antidiscrimination Law: A Critical Review." In D. Kairys, The Politics of Law: A Progressive Critique. New York, USA: Pantheon Books.

22. Friedman, M. 1962. Capitalism and Freedom. Chicago, USA: Chicago University Press.

23. Gava, J. 2010. "Dixonian Strict Legalism, Wilson v Darling Island Stevedoring and Contracting in the
Real World." Oxford Journal of Legal Studies, 30 (3): 519-543.

24. Gaze, B. and Smith, B. 2016. Equality and Discrimination Law in Australia: An Introduction. Cambridge, UK: Cambridge University Press.

25. Glasbeek, H. 2017. Class Privilege: How Law Shelters Shareholders and Coddles Capitalism.

Toronto, Canada: Between the Lines.

26. Goldberg, T. 2002. The Racial State. Oxford, UK: Blackwell.

27. Goldblatt, B. 2017. "Claiming Women's Social and Economic Rights in Australia." Australian Journal of Human Rights, 23 (2): 261-283.

28. Goldblatt, B. 2015. "Intersectionality in International Anti-discrimination law: Addressing Poverty in its Complexity." Australian Journal of Human Rights, 21 (1): 47-70.

29. Goldman, A. H. 1979. Justice and Reverse Discrimination. Princeton, USA: Princeton University Press.

30. Graycar, R. and Morgan, J. 2010. "Equality 'Unmodified."' In M. Thornton (ed.) Sex Discrimination in Uncertain Times. Canberra, Australia: ANU Press.

31. Green, P. 1981. The Pursuit of Inequality. Oxford, UK: Martin Robertson.

32. Green, T. K. 2017. Discrimination Laundering: The Rise of Organizational Innocence and the Crisis of Equal Opportunity Law. Cambridge, Mass. USA: Cambridge University Press.

33. Harvey, D. 2005. A Brief History of Neoliberalism. Oxford UK: Oxford University Press.

34. Hayne, J. 2020. “Australia must make Workplaces Coronavirus-safe and flatten the Unemployment Curve, Scott Morrison says." ABC News, 5 May. https://www.abc.net.au/news/2020-0505/coronavirus-national-cabinet-jobs-updatecovid19/12216454 Accessed 10/11/2020.

35. Jarvis Thomson, J. 1977. "Preferential Hiring." In M. Cohen, T. Nagel and T. Scanlon, Equality and Preferential Treatment. Princeton, USA: Princeton University Press. 
36. Kirby, N. 2018. "Two Concepts of Basic Equality." Res Publica, 24: 297-318.

37. Krieger, L. 1999. "Civil Rights Perestroika: Intergroup Relations After Affirmative Action." California Law Review, 86: 1251-1333.

38. Lawrence, C. R. III and Matsuda, M. J. 1997. We Won't Go Back: Making the Case for Affirmative Action. Boston, USA: Houghton Mifflin.

39. Lawton, A. 2000. "The Meritocracy Myth and the Illusion of Equal Employment Opportunity." Minneapolis Law Rev, 85: 587-661.

40. MacNaughton, G. 2018. "Equality Rights Beyond Neoliberal Constraints." In G. MacNaughton and D. F. Frey, Eds. Economic and Social Rights in a Neoliberal World. Cambridge, Mass., USA: Cambridge University Press.

41. Marx, K. 1938. Critique of the Gotha Programme. New York, USA: International Publishers.

42. Moens, G. 1985. Affirmative Action: The New Discrimination. Sydney, Australia: The Centre for Independent Studies.

43. Moyn, S. 2014. "A Powerless Companion: Human Rights in the Age of Neoliberalism." Law and Contemporary Problems, 77 (4): 147-169.

44. Nussbaum, M. C. 2011. Creating Capabilities: The Human Development Approach. Cambridge Mass., USA: Harvard University Press.

45. O’Connell, K. 2019. “Can Law address Intersectional Sexual Harassment? The Case of Claimants with Personality Disorders." Laws 8 (4): 34 https://doi.org/10.3390/laws8040034 Accessed 12/12/2020.

46. O’Donovan, K. and E. Szyszczak. 1988. Equality and Sex Discrimination Law. Oxford, UK: Basil Blackwell.

47. O'Neil, K. 2016. Weapons of Math Destruction: How Big Data Increases Inequality and Threatens Democracy. New York, USA: Crown.

48. Peetz, D. 2019. The Realities and Future of Work. Canberra, Australia: ANU Press.

49. Pender, K. 2019. Us Too? Bullying and Sexual Harassment in the Legal Profession. London: The International Bar Association (IBA).
50. Piketty, T. 2020. Capital and Ideology. Trans. A. Goldhammer. Cambridge, MA, USA: Harvard University Press.

51. Piketty, T. 2014. Capital in the Twenty-First Century. Trans. A. Goldhammer. Cambridge, MA, USA: Harvard University Press.

52. Purcell, M. 2008. Recapturing Democracy: Neoliberalization and the Struggle for Alternative Urban Futures. New York, USA: Routledge.

53. Radford, G. 1985. "Equal Opportunity Programs in the Australian Public Service.” In M. Sawer (ed.) Program for Change. Sydney, Australia: Allen \& Unwin.

54. Rawls, J. 1972. A Theory of Justice. Oxford, UK: Oxford University Press.

55. Rees, N., S. Rice and D. Allen. 2018. Australian Anti-discrimination and Equal Opportunity Law. 3rd edn. Sydney, Australia: Federation.

56. Rice, S. 2013, "Casenote: Joan Monica Maloney v The Queen [2013] HCA 28." Indigenous Law Bulletin, 8 (7): 28-32.

57. Rice, S. 2010. 'And Which "Equality Act" Would that Be?' in Margaret Thornton (ed.) Sex Discrimination in Uncertain Times. Canberra, Australia: ANU Press.

58. Rousseau, J. J. 1966. "A Discourse on the Origin of Inequality", in The Social Contract and Discourses. Trans. G. D. H. Cole. London, UK: Everyman's Library, Dent.

59. Sadurski, W. 1986. "Gerhardy v. Brown v. The Concept of Discrimination: Reflections on the Landmark Case that Wasn't." Sydney Law Review, 11: 5-43.

60. Scheidel, W. 2017. The Great Leveler: Violence and the History of Inequality from the Stone Age to the Twenty-First Century. Princeton, USA: Princeton University Press.

61. Sen, A. 2009. The Idea of Justice. Cambridge, Mass., USA: Harvard University Press.

62. Shulman, G. (2018). "Rethinking Equality". International Social Science Journal, 67: 11-20 https://doi.org/10.1111/issj.12151 Accessed $12 / 12 / 2020$. 
63. Somek, A. 2011. Engineering Equality: An Essay on European Anti-Discrimination Law. Oxford, UK: Oxford University Press.

64. Strachan. G. and Burgess, J. 2000. "W(h)ither Affirmative Action Legislation in Australia?" Journal of Interdisciplinary Gender Studies, 5 (2): 46-63.

65. Taylor, A. 2019. "The Conflicting Purpose of Australian Anti-Discrimination Law." UNSW Law Journal, 42 (1): 188-210.

66. Thornton, M. 2021. "Coronavirus and the Colonisation of Private Life." Legalities, 1 (1): 44-67.

67. Thornton, M. 2018. "Social Status: The Last Bastion of Discrimination." Anti-Discrimination Law Review, 1 (3): 5-26.

68. Thornton, M. 2016. "The Flexible Cyborg: WorkLife Balance in Legal Practice." Sydney Law Review, 38 (1): 1-21.

69. Thornton, M. 2015. "The Political Contingency of Sex Discrimination Legislation: The Case of Australia." Laws, 4: 314-334.

70. Thornton, M. 2008. "Sex Discrimination, Courts and Corporate Power." Federal Law Review, 36(1): 31-56.

71. Thornton, M. 1990. The Liberal Promise: Anti-Discrimination Legislation in Australia. Melbourne, Australia: Oxford University Press.

72. Thornton, M. and Luker, T. 2010. "The New Racism in Employment Discrimination: Tales from the Global Economy." Sydney University Law Review, 32 (1): 1-27.

73. Thornton, M. and Luker, T. 2010. "The Sex Discrimination Act and its Rocky Rite of Passage." In M. Thornton, Ed. Sex Discrimination in Uncertain Times. Canberra, Australia: ANU E Press.

74. Turkle, S. 2011. Alone Together: Why We Expect More from Technology and Less from Each Other. New York, USA: Basic Books.

75. Wacquant, L. 2009. Punishing the Poor: The Neoliberal Government of Social Security. Durham, N.C. USA: Duke University Press.

76. Waldron, J. 2008. "Basic Equality." New York: "Public Law \& Legal Theory", Research Paper Series, Working Paper No 08-61, New York University.
77. Wilenski, P. 1977. Review of New South Wales Government Administration: Directions for Change. Sydney, Australia: NSW Government Printer.

78. Williams, G. 1999. Human Rights under the Australian Constitution. Melbourne, Australia: Oxford University Press.

79. Wolgast, E. H. 1980. Equality and the Rights of Women. Ithaca, USA: Cornell University Press.

\section{Legislation}

Affirmative Action (Equal Opportunity for Women) Act 1986 (Cth).

Age Discrimination Act 2004 (Cth).

Anti-Discrimination Act 1991 (ACT).

Charter of Human Rights and Responsibilities Act 2006 (Vic).

Equal Opportunity Act 2010 (Vic).

Equal Opportunity for Women Act 1999 (Cth).

Gender Equality Act 2020 (Vic).

Human Rights Act 2004 (ACT).

Human Rights Act 2019 (Qld).

Pitjantjatjara Land Rights Act 1981 (SA).

Racial Discrimination Act 1975 (Cth).

Workplace Gender Equality Act 2012 (Cth).

\section{Case law}

Australia

Ansett Transport Industries (Operations) Pty Ltd $v$ Wardley (1980) 142 CLR 237.

DLH v Nationwide News Pty. Ltd. (No. 2) [2018] NSWCATAD 217.

Duncan v Chief Exec., Office of Environment and Heritage No. 2) (2013) NSWADT 78.

Findley v MSS Security Pty. Ltd. [2017] FCCA 2898.

Frost $v$ TAFE NSW [2020] NSWCATAD 219.

Gerhardy v Brown (1985) 159 CLR 70.

Leeth v Commonwealth (1992) 174 CLR 455.

Liria v Papuan Oil Search Ltd. [2012] NSWADT 73.

Macca $v$ Australian Capital Territory represented by Emergency Services Agency (Discrimination) [2017] ACAT 101.

Maloney v The Queen (2013) 252 CLR 168. 
Munkara v Bencsevich \& Ors. [2018] NTCA 4.

Sahak $v$ Minister for Immigration and Multicultural Affairs (2002) 123 FCR 541.

State of New South Wales v Amery (2006) 226 ALR 196, 230.

United States

International Brotherhood of Teamsters $v$ United States (431 US 324 (1977)
Regents of University of California v Bakke 438 US 165 (1978).

\section{International instruments}

International Labour Organisation 111 (Convention concerning Discrimination in respect of Employment and Occupation), ratified by Australia in 1973. 